other places in New Zealand, Australia, Fiji and Tonga, continuing her work among the needy, the sick, those on the margins of society and with the same single-minded purpose: 'We must be all for God and God must be all for us'.

So often we have debated with great diversity of opinion, what would she do today? How would she meet today's challenges? You have kept the vision of Suzanne alive, allowing it to endure through all kinds of obstacles. More than that: you have enabled it to blossom in new ways, into new cultures, in new times, you have 'depthed' her spirit. Her vision has become our vision. Without you the story would be history but it is - her story and our story.

Jessie completes the Epilogue: 'Bridging gaps was what Suzanne Aubert did best, and with an inviting confidence she directed those around her to do just the same'. She still does.

Throw a plant across the stream for us to cross to the other side: Kahupapangia te awa ki te rakau kia whiti tatou ki tera taha.

\section{(1) BOOK REVIEW}

\section{Elegance, mystery, autumnal sadness ...}

\section{The Opawa Affair}

\section{Edmund Bohan, Hazard Press, 1996}

\section{Reviewed by Nelson Wattie}

$\mathrm{I}^{\mathrm{N}}$

N THE ROBERT MCDOUGALL GALLERY in Christchurch there is a very striking and mysterious painting by G.D.Leslie called The Wizard's Garden. At the side of a moat in a well-trimmed garden stands an elegant shapely figure in a red, very impractical gown. She holds herself proudly - like a singer. Her eyes contrive to be both hauntingly sad and slightly surprised at the same time, while her small mouth suggests seriousness of purpose. Through an arched gateway in a high containing wall comes a dark figure in broad-rimmed hat and long robe, barely more than a silhouette, and again ambiguous: either threatening or friendly, depending on how your eyes are trained.

This painting graces the cover of Edmund Bohan's 19th-century mystery novel - a nice piece of book design - and suggests much of what is inside: elegance, mystery, autumnal sadness, careful design and a pre-Raphaelite sensuality. Although short, it is a book of several dimensions.

There is the Christchurch dimension: it is taken for granted that class distinctions divide this society almost as cleanly as Edward Gibbon Wakefield would have wanted, and that the top layer is an almost unapproach-

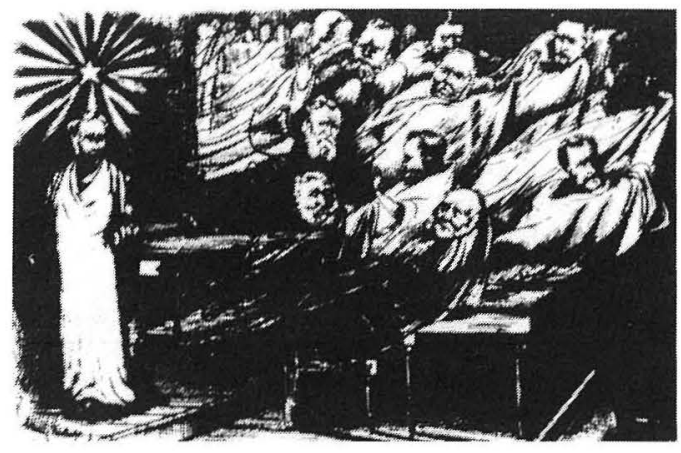

able, effete anglophile group, frustrating the Irish and lower-class investigator by setting up barriers as high as the wall in the painting. This is a leisured, sophisticated, relatively educated world with a seething under-surface of servants, policemen and prostitutes. And at its centre a medievalising cathedral is being constructed.

'Have a care, my good fellow! Mr Allen is a gentleman of the most exquisite breeding and, I believe, connected to the English nobility. Perhaps you are not aware of that fact?'.

'I'm aware that I'm investigating a murder, Sir. I need to know anything that might be relevant to that investigation'.

'Then do not let me hear you impugning the integrity of people of the Allen's rank, Sergeant O'Rorke!'.

Clearly, there is an Irish dimension, too. The most surprising people knew each other on the emerald isle before finding themselves stranded on the mainland. The victim and the policeman, for example; and the policeman and an Italian opera singer known to most as Tomaso Briani and to a few as Thomas O'Brien. The class distinctions have a strong national undertone and barriers can be breached in part by the solidarity of the Irish against the rest of the world.

There is the historical dimension, unsur-prisingly in one of the country's finest historical biographers. Here Bohan's erudition is worn lightly, but one feels secure in following his narrator through the atmosphere of time and place. Historical figures fit easily beside the fictitious ones and are treated as people with weaknesses rather than respected as icons. This is especially true of George Grey whose efforts to win an election emerge from the story here and there, but whose liking for the ladies is even more strongly featured. Bohan is, I believe, to write a biography of George Grey and again one can feel secure with this image, limited and briefly glimpsed though it is. But such historical features - they include Julius von Haast, laden with learning - are not permitted to take over or

Above: Sir George Grey's efforts to win the 1879 general election were depicted in New Zealand Punch. Sir George 'in a halo of light' is being deserted by his followers, the 'Auckland rats'. Canterbury Public Library. 
hold up the course of the fictional action.

There is an operatic dimension. One of those opera companies that Adrienne Simpson has so tirelessly researched is in town with Italianate performers, curious in behaviour and in name - a leading lady is called Gabriella Sabatini. After a while one feels the need to give even the New Zealand singer, Frances Grace, the benefits of an Italian pronunciation to her family name. Productions of Maritana, Les Huguenots and Il Barbiere di Seviglia are lovingly described. Here the author's special interests (he was an opera singer for a quarter of a century) do tend to get in the way of things, and readers less interested in operatic history than he, might feel that the plots of stageworks stand in the way of the novel's own plot - but only for a very few pages. The fluidity of the company singers coming and going, rising and declining, falling ill and overcoming their weaknesses, and struggling through to the best possible performances in spite of it all - definitely add a dimension to the tale itself. The visits of certain singers to certain all-night houses reveal some of the underlying mystery and the element of uncertainty, so central to a mystery novel, is increased by the ups and downs of the opera company's fate.

The air of mystery is all-pervasive. It is not just a matter of whodunit but also of the private and even secret lives of many characters. Sexual misbehaviour, even perversion, is constantly hinted at; the veil is lifted and falls again before one has quite glimpsed what is behind it; highly respectable persons seem filled with highly sensual ill-will. It is a relief to contemplate the honest Irish love of the policeman for his Shannon girl - unfortunately murdered. In fact the least satisfactory thread in this interweave is the actual murder plot itself. Don't read this book for its ending, but do read it. There are lots of satisfactions and interesting curiosities along the way.

\section{(1i) BOOK REVIEW}

\section{A very readable narrative}

\section{The Mother of All Departments: The History of the Department of Internal Affairs}

\section{Michael Bassett, Auckland University Press, 1997, pp.312.}

\section{Reviewed by John R. Martin}

$\mathrm{E}$ VERY GOVERNMENT NEEDS ONE - a catch-all agency in which can reside those administrative chores which do not fit neatly into functional pigeonholes. The British have the Home Office; the Australians the Department of Administrative Services. In New Zealand the Department of Internal Affairs has taken that role. It has been, in Sir Jack Hunn's phrase, a repository for 'waifs and strays' ${ }^{1}$. But Internal Affairs also had the distinction, as the Colonial Secretary's office from 1840, of being as Michael Bassett puts it 'the source of administrative power in the new land and the constitutional fount of bureaucratic authority'. ${ }^{2}$ Hence, 'the Mother of all Departments'.

Over the decades since 1840 Internal Affairs has shed many functions and gained others. There have been times when its activities have been of high political salience. But for most of its history it has simply been a fixture in the machinery of government. Bassett has taken a vast amount of archival material and drawn from it a very readable narrative which illuminates some of the less frequently visited corners of the bureaucracy.

The Centennial publications of 1940 and the War Histories - both centred on Internal Affairs - made major contributions to New Zealand's institutional history. But for nearly 50 years after World War II the only substantial books on the history of public administration - there were informative articles in, for example, the New Zealand Journal of Public Administration - were Lipson's Politics of Equality $(1948)^{3}$ and Polaschek's Government Administration in New Zealand (1958). ${ }^{4}$ The sesquicentennial of 1990 was marked by a welcome increase in departmental histories, notably but not exclusively, Alan Henderson's work on the SSC and its predecessor, the Public Service Commission, John E. Martin's history of the Department of Labour, ${ }^{6}$ and a number of contributions to the story of New Zealand's dealings with the rest of the world. ${ }^{7}$ The Historical Branch of Internal Affairs with the backing of Michael Bassett, as Minister from 1987-1990, was instrumental in promoting this activity. Its importance was underlined by the unprecedented restructuring of government agencies initiated in the mid-80s and the consequential threat to departmental records.

Institutional histories, given the inevitable constraints on the word-count, pose particular problems for historians. One concerns the balance among the decades. In the New Zealand case, should the archival material of the nineteenth century be ploughed to produce a record of colonial achievement, and sometimes failure - but at the expense of the excitement of the last decade? This tends to have been the pattern of recent departmental histories. The Mother of All Departments takes the other route: about a quarter of the text is devoted to the period since 1970. For the contemporary readership there is the attraction of reading about people and events of your acquaintance. The cost - and one about which I have some regrets in this case - is a thinner treatment of the earlier times when the role of Internal Affairs was of greater significance in the context of government as a whole.

The second dilemma for an historian of what, in the world of business, would be categorised as a 'conglomerate' $^{\prime}$ is how to impose some order on the raw material. Bluntly, what to leave in or out. Bassett has chosen to concentrate on 'the core entity called Internal Affairs as it 